Special Issue: Agricultural Productivity and Sustainability Improvement in Tropical Region

\title{
Potential of Aloe vera for Treatment of Infection with Aeromonas bydrophila Bacteria on Koi Fry
}

\author{
Rosidah Rosidah $^{1 *}$,Angga Nugraha ${ }^{1}$,Yuli Andriani ${ }^{1}$, Kiki Haetami $^{1}$, Olga Anne $^{2}$ and Agus Heri Purnomo ${ }^{3}$ \\ ${ }^{1}$ Department of Fisheries, Faculty of Fisheries and Marine Science, Universitas Padjadjaran, Jl. Raya Bandung, Sumedang Km \\ 21, Jatinangor 45363, West Java, Indonesia; ${ }^{2}$ Technology and Natural Sciences Faculty, Klaipeda University, Herkaus Manto \\ g. 84, Klaipeda 92294, Lithuania; ${ }^{3}$ Research Center for Marine and Fisheries Sosio-economics, Ministry of Marine Affairs and \\ Fisheries, Republic of Indonesia, Gedung Mina Bahari 1, Jl. Pasir Putib 1, Ancol, Jakarta 14430, Indonesia.
}

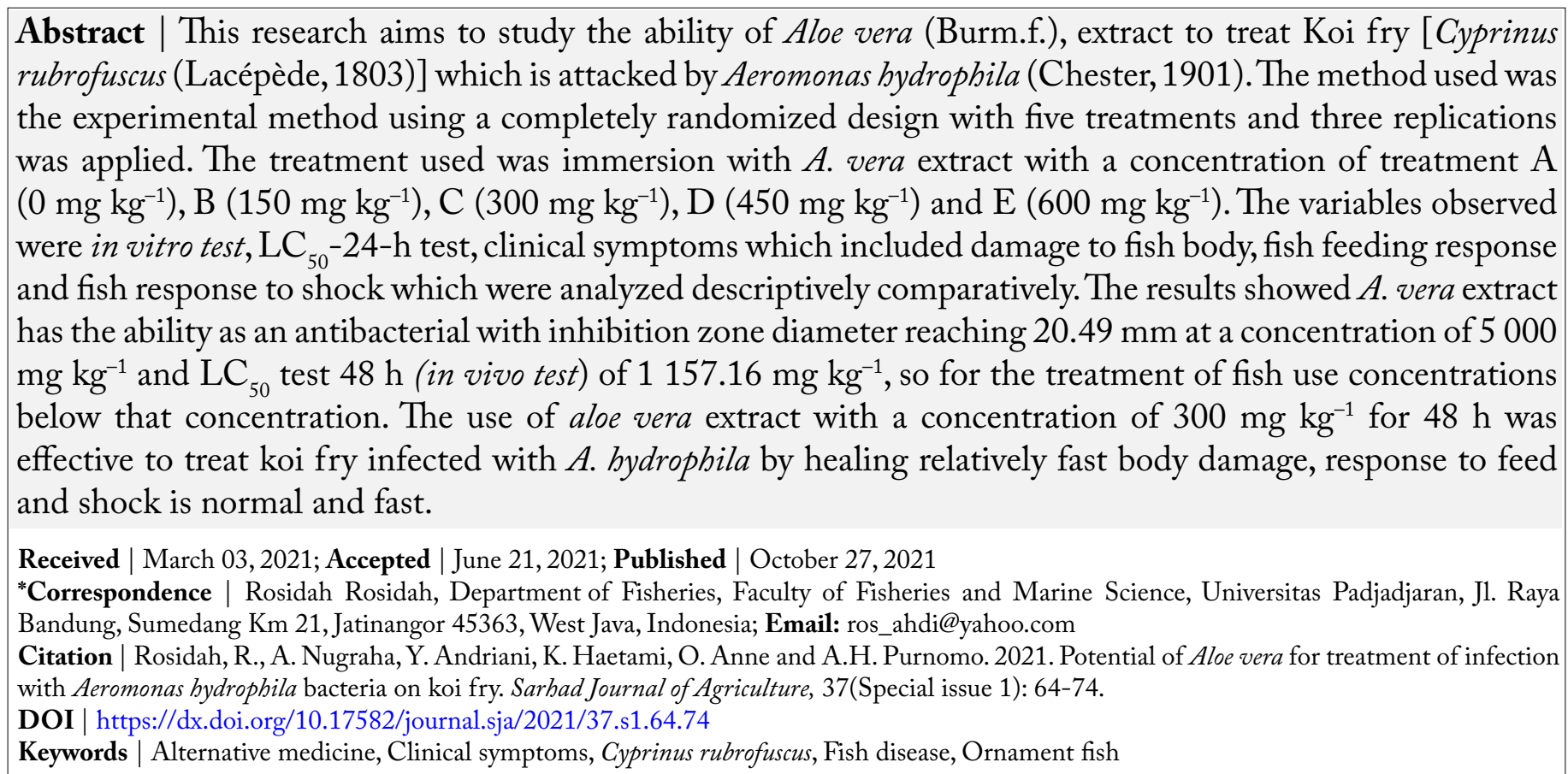

\section{Introduction}

$\mathrm{O}$ ne of the highly prospective ornamental fish, the technology that is controlled by farmers is Koi fry [Cyprinus rubrofuscus (Lacépède, 1803)]. The marketing of Koi by exporters includes Germany, Africa, England, Singapore, and America. The constraints faced by exporters to meet consumer demand are the low availability of quality Koi fish (Triyanti and Yulisti, 2012), while the obstacles faced by farmers are the attack of Motile Aeromonas Septicemia (MAS) or red spot disease caused by bacteria Aeromonas bydrophila (Chester, 1901). One of the diseases that often attack freshwater fish, one of which is Koi, especially in the fry stages.

Aeromonas hydrophila is an opportunistic type of pathogenic bacteria and can cause systemic diseases and result in mass death (Peatman et al., 2018). $A$. bydrophila is a gram-negative, rod-shaped, size (0.8 to 1.0$) \mu \mathrm{m} \times(1.0$ to 3.5$) \mu \mathrm{m}$. These bacteria can move (motile) and do not form spores. These bacteria are facultatively anaerobic, fermentative, positive cytochrome oxidase, positive catalase and produce $\mathrm{H}_{2} \mathrm{~S}$ 
(Wassif, 2018). Laith and Najiah (2013) stated that the clinical symptom of fish attacked by $A$. bydrophila is inflammation with a characteristic swelling in the injection site. These symptoms continue with haemorrhagic (bleeding) which is characterized by the discharge of blood on the skin, the flake fin and slow swimming fins, exophthalmia (swollen eyes), ulcers (ulcers in the body) and necrosis are symptoms that are characterized by the appearance of damaged and decaying flesh.

Disease prevention in the cultivation system generally uses antibiotics. However, the use of antibiotics can cause a resistant effect on pathogenic bacteria and cause pollution to the environment (Kraemer et al., 2019). Therefore, other alternative drugs that are more environmentally friendly and do not cause a resistant effect on bacteria, $A$. vera extract are needed.

According to Khan and Ayub (2020) A. vera leaves have a wide therapeutic effect, including being used as a diarrhea medicine, boosting the immune system, preventing tumors, maintaining the liver, preventing gastric inflammation, healing inflamed or injured tissue etc. Kar and Bera (2017) stated that, all parts of extracted $A$. vera, contain polysaccharides (acemannan and glucomannan), flavonoids, tannins, and saponins. According to Quezada et al. (2017), the two main polysaccharides contained in $A$. vera are glucomannan and acemannan. Glucomannan acts to replace skin tissue and reduce pain due to injury. Friendship can accelerate wound healing. Flavonoids are anti-inflammatory so can reduce inflammation and help reduce pain if there is bleeding or inflammation in the wound (Panche et al., 2017). Tanin is useful as an antiseptic and also for the treatment of burns by prescribing proteins (Huang et al., 2018). The mechanism of action of saponin as an antibacterial is to damage the constituent components of peptidoglycan on the bacterial cell wall (lipoprotein). This results in decreased lipid surface tension, changing cell permeability, and the mechanism can cause bacterial cell function to be abnormal, and lysis and dead cell bacteria (Hamouda and Baker, 2019).

The right way to treat Koi fish which is attacked by MAS is by dipping. According to (Kumar et al., 2018), that treatment with an immersion system is the most applicable method compared to injection and feeding because it can simplify the treatment process especially for fish in the size of on a large scale.

\section{Materials and Methods}

This research includes preliminary research and main research. Preliminary research is carried out on March 4 to 10,2019 and the main research will be conducted for $2 \mathrm{wk}$ (weeks) in March and April. This research took place at the Gd 4 Aquaculture Laboratory, Fisheries and Agricultural Engineering and Biotechnology Laboratory; Gd. 3 Faculty of Fisheries and Marine Sciences, Padjadjaran University, Indonesia. The method used in this research is the experimental method using Completely Randomized Design (CRD) with five treatments and three replications. The treatment given was soaking Koi fry infected with $A$. bydrophila in $A$. vera extract with a concentration based on the results of in vitro and in vivo tests, as follows:

Treatment A: Control treatment without $A$. vera immersion; Treatment B: $150 \mathrm{mg} \mathrm{kg}^{-1}$ A. vera extract; Treatment C: $300 \mathrm{mg} \mathrm{kg}^{-1} A$. vera extract; Treatment D: $450 \mathrm{mg} \mathrm{kg}^{-1} A$. vera extract; Treatment E: $600 \mathrm{mg}$ $\mathrm{kg}^{-1} A$. vera extract.

\section{Research procedure}

The preparation of experimental Koi fry: The experimental fish used in this study originated from Center for Research and Development of Freshwater Aquaculture (BBPBAT- Balai Besar Perikanan Budidaya Air Tawar) in Sukabumi, West Java, sizing of $8 \mathrm{~cm}$ to $12 \mathrm{~cm}$ in total length, as much as 80 fishes for the initial study, 300 fishes for the further study. The experimental fishes were acclimatized for $7 \mathrm{~d}$ (days) to find out the healthy fish.

The preparation of aquarium: As much as 15 aquariums sizing of $40 \mathrm{~cm} \times 30 \mathrm{~cm} \times 20 \mathrm{~cm}$ were used in this study. The aquariums were cleaned, then the water was added fully and as much as $30 \mathrm{mg} \mathrm{L}^{-1}$ of chlorine was added to sterilize the containers for 24 . The aquariums were dried before being used. After that, the aqariums were filled with $20 \mathrm{~L}$ of water and were aerated.

\section{The preparation of $A$. vera extract}

$A$. vera extract was prepared by maceration method (Sopiah et al., 2018). As much as $3000 \mathrm{~g}$ of wet $A$. vera were dried for $14 \mathrm{~d}$. The dried $A$. vera were performed by using $92 \%$ methanol solution as much as $35 \mathrm{~L}$ for $3 \mathrm{~d}$. The filtrate was filtered by using Whatman paper filter number 42 . The maceration 
filtrate was evaporated and concentrated by using rotatory evaporator at $80{ }^{\circ} \mathrm{C}$ to obtain the $A$. vera thick extract as much as $228.3 \mathrm{~g}$.

\section{Preliminary in vitro tests}

The zone of inhibition used to test the effectiveness of Aloe vera extract as an antibacterial to inhibit the growth of A.hydrophila by using the USEPA Method (2002). The zone of inhibition was used disk diffusion test with four variances of Aloe vera extract concentration: $10 \mathrm{mg} \mathrm{kg}^{-1}, 100 \mathrm{mg} \mathrm{kg}{ }^{-1}, 1000 \mathrm{mg}$ $\mathrm{kg}^{-1}$, and $5000 \mathrm{mg} \mathrm{kg}{ }^{-1}$ for $48 \mathrm{~h}$. The material and equipment were sterilized using an autoclave. The disc paper was put to a petri dish with NA medium and $1 \mathrm{~mL}$ of $A$. bydrophila inoculation (the bacteria

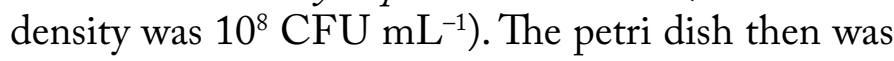
incubated for $24 \mathrm{~h}$ at $30^{\circ} \mathrm{C}$. The zone of inhibition was measured by using a caliper.

\section{LC50-24-hour test}

The LC50 test of $A$. vera extract was done to measure the short-term poisoning potential which causes $50 \%$ of mortality. The concentration for LC50 consisted four treatments $\left(10 \mathrm{mg} \mathrm{kg}^{-1}, 100 \mathrm{mg} \mathrm{kg}{ }^{-1}\right.$, $1000 \mathrm{mg} \mathrm{kg}^{-1}$ and $5000 \mathrm{mg} \mathrm{kg} \mathrm{kg}^{-1}$ ) with two replications. The experimental fish was acclimatized in fiber container with $100 \mathrm{~L}$ of water for $7 \mathrm{~d}$. Fish with the same weight and size transferred into an aquarium with $5 \mathrm{~L}$ of water and stocking density of 10 fishes aquarium ${ }^{-1}$. The $A$. vera extract added into each aquarium according to the treatments. The survival rate of fish has measured with EPA probit analysis software.

\section{Fish infection}

The experimental method used in this study was complete randomized design (CRD) with five treatments and three replications, consisted $\mathrm{A}$ (control), B (150 mg kg-1 m), C (300 mg kg-1), D (450 $\left.\mathrm{mg} \mathrm{kg}{ }^{-1}\right)$, and $\mathrm{E}\left(600 \mathrm{mg} \mathrm{kg}{ }^{-1}\right)$. Infection of fish with $A$. bydrophila bacteria was carried out intramuscularly on fish that had been acclimatized for $7 \mathrm{~d}$. The density of bacteria injected $10^{8} \mathrm{CFU} \mathrm{mL} \mathrm{m}^{-1}$ as much as $0.1 \mathrm{~mL}$. After being infected, fish reared in an aquarium and given artificial feed twice a day, at 08.00 and 16.00 WIB (West Indonesia Time) as much as $3 \%$ of the body's biomass in an adlibitum. If clinical symptoms occur immediately treated. Clinical symptoms (body damage, food response, shock response) observed after fish were infected with $A$. bydrophila bacteria. If clinical symptoms occur immediately treated with
A. vera extract according to treatment.

\section{Treatment of infected koi fry}

Treatment of Koi fry that have been infected with A. bydrophila is done by soaking them in a solution of Aloe vera extract $48 \mathrm{~h}$. After treatment, the fish were transferred to aquarium maintenance for $14 \mathrm{~d}$ while observing their recovery. Observed variables include body damage, response to feeding and behavior (Haryani et al., 2012)

\section{Results and Discussion}

\section{In vitro test}

The results of the inhibitory zone test (in vitro) showed that the concentration of $A$. vera extract at $5000 \mathrm{mg} \mathrm{kg}^{-1}$ had the largest average inhibition zone of $20.49 \mathrm{~mm}$, whereas at a concentration of $10 \mathrm{mg} \mathrm{kg}^{-1}$ the average smallest inhibition zone was $8.39 \mathrm{~mm}$. A. vera concentration of $5000 \mathrm{mg} \mathrm{kg}^{-1}$ is a relatively strong antibacterial. As the opinion of Bereksi et al. (2018) the diameter of the inhibition zone of $20 \mathrm{~mm}$ is categorized as a medium inhibition zone, whereas above $20 \mathrm{~mm}$ is categorized as strong. According to Samsudin et al. (2018) the diameter of inhibition zone $\leq 12 \mathrm{~mm}$ is categorized as low and the diameter of inhibition zone $13 \mathrm{~mm}$ to $14 \mathrm{~mm}$ is categorized as medium and the diameter of inhibition zone above $14 \mathrm{~cm}$ is categorized as strong in inhibiting bacterial growth. The ability of $A$ vera extract to inhibit the growth of $A$. bydrophila bacteria is due to the presence of secondary metabolite content including polysaccharides (acemanan and glucomannan), flavonoids, tannins and saponins that act as antimicrobials. Glucomannan and acemannan have been proved to accelerate wound healing, activating macrophages, stimulating immune system as well antibacterial and antiviral effects (Sahu et al., 2013). Elayaraja et al. (2015) stated that antimicrobial activity is caused by the presence of terpenoid compounds in plant extracts that can damage the cell walls of bacteria that form complex compounds with cellular extracts, so that proteins and microbial cell walls are destroyed. Besides that antibacterial activity is also caused by the presence of phenolic compounds (tannins and flavonoids) contained in the extract. Mandal et al. (2017) states the antibacterial activity of plant extracts can be attributed to the high content of phenols and flavonoids. Several studies have shown the antibacterial effect of secondary metabolites in inhibiting various types of bacteria. 
Phenolic compounds and especially flavonoids can act as antimicrobial agents through several different mechanisms, including inhibiting nucleic acid synthesis, inhibiting cytoplasmic membrane function, inhibiting energy metabolism, inhibiting biofilm adhesion and formation, inhibiting porin in cell membranes, changing membrane permeability, which can cause damage to membrane cells, and weakening pathogenicity (Safaria and Asbchinb, 2019). Opinion of Sengul et al. (2009) phenolic compounds are synthesized by medicinal plants in response to microbial infections, so in vitro testing is an effective antimicrobial agent against a variety of pathogenic microorganisms.

Table 1: Inbibit zone Aloe vera extract.

$\begin{array}{ll}\text { Concentration }\left(\mathbf{m g ~ k g}^{-1}\right) & \text { Average inhibitory zone } \\ 10 & 8.39 \\ 100 & 9.77 \\ 1000 & 11.32 \\ 5000 & 20.49\end{array}$

In vivo test

The results of the $\mathrm{LC}_{50}$ immersion test $48 \mathrm{~h}$ (in vivo) $A$. vera extract on koi fry showed that the concentration of $A$. vera extract analyzed using EPA Probit Analysis software found a concentration of $1157.16 \mathrm{mg} \mathrm{kg}{ }^{-1}$ could kill fish as much as $50 \%$ of total individuals. while the concentration of $304.95 \mathrm{mg} \mathrm{kg}^{-1}$ can kill fish as much as $15 \%$ of the total individuals. This shows that the safe concentration for fish for the treatment of disease is below $1157.16 \mathrm{mg} \mathrm{kg}{ }^{-1}$. Some of the active compound in $A$. vera extract will be toxic if the concentration is too high, especially for saponin. Saponin is completely cytotoxic. This was in line with Septriarusli et al. (2012), saponin is a toxin that will ruin the blood cell (hemolysis). The potential of secondary metabolites in plants as antimicrobials can be used by suppressing antimetabolic and toxic contents, one of which is to pay attention to the concentration of the plant extract (Chakraborty, 2013).

\section{Clinical symptoms}

Observation of the clinical symptoms of Koi fry infected by $A$. hydrophila includes body damage and changes in the behavior of Koi fry. Body damage includes (ulcer, hemorrhagic, exophthalmia, dropsy, discoloration, ulcers, flaky fins) whereas observed behavioral changes include response to feed and response to shock.
Body damage

Infected Koi fry by $A$. bydrophila shows early clinical symptoms within $7 \mathrm{~h}$ after infection. This is in accordance with Haryani et al. (2012) research that clinical symptoms due to infection with $A$. bydropbila bacteria in carp fish appear after $4 \mathrm{~h}$ to $7 \mathrm{~h}$ after infection. The clinical symptoms seen at the outset were inflammation in the injection site (Figure 1a) and red (hemorraghic) spots in fish (Figure 1b), this occurred in all treatments.

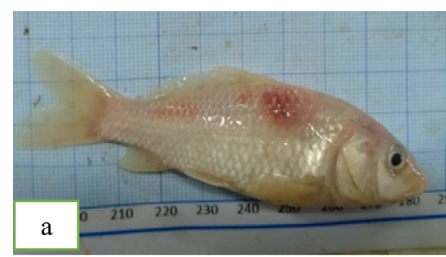

Figure 1: Early clinical (b) hemorraghic

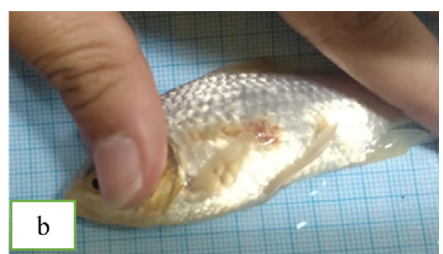

(a) inflammatory,
According to Haryani et al. (2012) clinical symptoms of fish attacked by $A$. bydrophila bacteria or Motile Aeromonas Septicemia (MAS) disease characterized by inflammation by swelling and redness of the injection site and then appearing hemorraghic on the fish body. According to Pandey et al. (2010) the emergence of redness (hemorraghic) on the surface of the fish body is caused by the activity of hemolysin enzymes produced by the bacterium $A$. bydrophila with the target of breaking down red blood cells, so that the cells come out of the blood vessels and cause redness on the skin surface. According to Hamid et al. (2016) $A$. bydrophila bacteria degrade body organ tissues and secretes toxins in the form of hemolysin which is spread throughout the body through the bloodstream causing inflammation.

After visible damage to the body in the form of hemorraghic appeared evenly, Koi fry was immediately given treatment by immersion using aloe vera extract for $48 \mathrm{~h}$. Observation of the clinical symptoms of Koi fry is carried out after infection and treatment with aloe vera extract. After treatment with $A$. vera extract, body damage in Koi fry experienced healing which differed in each treatment and in each time of observation (Table 2).

Based on Table 1 on $1^{\text {st }} \mathrm{d}$ to $3^{\text {rd }} \mathrm{d}$ post-treatment, koi fry bodies in all treatments experienced ulcers (Figure 2a). According to Lukistyowati and Kurniasih (2012), ulcers can occur because the regeneration of damaged cells runs slower than the cell death that occurs). This 
is reinforced by the statement of Kozińska and Pekala (2012) that the occurrence of ulcers is caused by the high density of $A$. hydrophila bacteria in the target organs, so that the volume and intensity of toxins released in the infectious process are also higher in that part, while others enter the body blood flow.

Table 2: Damage to Koi fry after treatment.

\begin{tabular}{|c|c|c|c|c|c|}
\hline \multirow[t]{2}{*}{ Day } & \multicolumn{5}{|c|}{ Body damage } \\
\hline & $\begin{array}{l}\text { A }(0 \mathrm{mg} \\
\left.\mathrm{kg}^{-1}\right)\end{array}$ & $\begin{array}{l}\mathrm{B}(150 \mathrm{mg} \\
\left.\mathrm{kg}^{-1}\right)\end{array}$ & $\begin{array}{l}\mathrm{C}(300 \\
\left.\mathrm{mg} \mathrm{kg}^{-1}\right)\end{array}$ & $\begin{array}{l}\mathrm{D}(450 \\
\left.\mathrm{mg} \mathrm{kg}{ }^{-1}\right)\end{array}$ & $\begin{array}{l}\mathrm{E}(600 \\
\left.\mathrm{mg} \mathrm{kg}^{-1}\right)\end{array}$ \\
\hline 1 & UHP & UHP & UHP & UHGP & UHP \\
\hline 2 & UHP & UHP & UHP & UP & - \\
\hline 3 & UHPG & UHP & UHP & UP & - \\
\hline 4 & UHPG & UPB & UP & UP & - \\
\hline 5 & UHP & UPB & UP & $\mathrm{H}$ & - \\
\hline 6 & UHP & UP & UP & $\mathrm{H}$ & - \\
\hline 7 & UHPB & $\mathrm{P}$ & $\mathrm{H}$ & $\mathrm{H}$ & - \\
\hline 8 & UHPB & $\mathrm{P}$ & $\mathrm{H}$ & $\mathrm{H}$ & - \\
\hline 9 & UHPB & $\mathrm{P}$ & $\mathrm{H}$ & $\mathrm{H}$ & - \\
\hline 10 & UHPBG & $\mathrm{P}$ & $\mathrm{H}$ & $\mathrm{H}$ & - \\
\hline 11 & UHPBGED & $\mathrm{H}$ & $\mathrm{H}$ & $\mathrm{H}$ & - \\
\hline 12 & UHPBGE & $\mathrm{H}$ & $\mathrm{H}$ & $\mathrm{H}$ & - \\
\hline 13 & UHPG & $\mathrm{H}$ & $\mathrm{H}$ & $\mathrm{H}$ & - \\
\hline 14 & UHPG & $\mathrm{H}$ & $\mathrm{H}$ & $\mathrm{H}$ & - \\
\hline
\end{tabular}

Description: $U=$ Ulcer; $B=$ Enlarged ulcer; $H=$ Hemorraghic $E^{\circ}$ inflammatory; $E=$ exophthalmia; $P=$ Discolored; $D=$ Dropsy; $G=$ Flake fin; $\mathrm{H}=$ Heal; -= Dead.

Koi fry treatment $A$ (control) on the $7^{\text {th }} d$ the ulcer enlarged to become ulcers. According to Mustaqim et al. (2017) ulcers that begin to enlarge can cause the meat to be damaged to cause an enlarged ulcer (Figure 2b). In addition to experiencing ulcers and enlarged ulcer Koi fry in treatment $A$ also experience prominent eyes (exophthalmia) and distended stomach (dropsy) (Figure 2c, d). According to Noor El-Deen et al. (2013) exophthalmia occurs because the accumulation of fluid toxins in the eye causes the eyeball to become convex and protrude as a result of bleeding around the eyes, while dropsy occurs because the flow of body fluid stops and seeps out of the capillary and enter into organ, body cavities, and eye cavities. On observation of $1^{\text {st }} \mathrm{d}$ of Koi fry in treatment $\mathrm{A}$, body damage was getting worse and worse, resulting in many deaths at the end of the study, because the koi fry in treatment $\mathrm{A}$ that are infected with $A$. bydrophila are not given the natural body treatment and defense of the fish which is not able to fight the attack of $A$. hydrophila bacteria.

Koi fry in treatment $B\left(150 \mathrm{mg} \mathrm{kg}^{-1}\right)$ on $4^{\text {th }} \mathrm{d}$ and $5^{\text {th }} \mathrm{d}$ experienced enlarged ulcers but were not as severe as in treatment $\mathrm{A}\left(0 \mathrm{mg} \mathrm{kg}^{-1}\right)$ then fish died on $6^{\text {th }} \mathrm{d}$, ulcers in treated fish B (150 mg kg $\mathrm{kg}^{-1}$ ) gradually increased shrinking until the fish only experience pale color on $7^{\text {th }} \mathrm{d}$. According to Kartikaningsih et al. (2020), fish that looks stressed in their body color will look pale and the pattern looks clearer. Koi fry has fully recovered on $11^{\text {th }} \mathrm{d}$, the healing process which is relatively long in treatment $B$ is suspected because antibacterial compounds at a concentration of 150 $\mathrm{mg} \mathrm{kg}{ }^{-1}$ are still not enough to treat body damage due to $A$. bydrophila that appears on Koi fry.

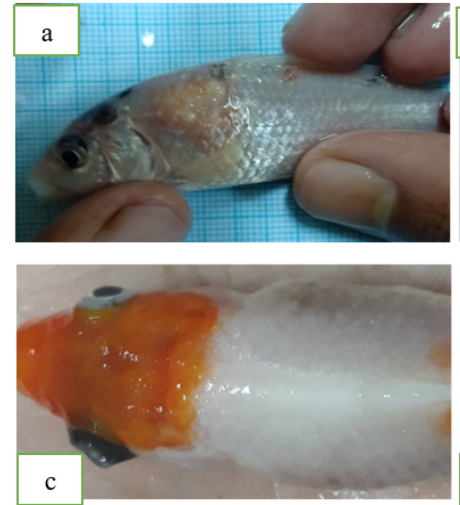

Figure 2: Clinical symptoms of $A$. bydrophila (b) enlarged ulcer, (c) exophthalmia, and (d) dropsy

The Koi fry in treatment $\mathrm{C}\left(300 \mathrm{mg} \mathrm{kg}^{-1}\right)$ hemorraghic and ulcers began to heal on the $6^{\text {th }} \mathrm{d}$ which was marked by hemorrhagic disappearance and ulcers began to shrink on $4^{\text {th }} \mathrm{d}$ (Figure 3a), total healing occurred on $7^{\text {th }} \mathrm{d}$. Because the concentration of aloe vera extract is high, then the treatment is faster. Seen from healing treatment $\mathrm{C}\left(300 \mathrm{mg} \mathrm{kg}{ }^{-1}\right)$ which is faster than treatment $\mathrm{B}\left(150 \mathrm{mg} \mathrm{kg}{ }^{-1}\right)$. The higher the concentration of an antibacterial ingredient the stronger the antibacterial activity.

Koi fry in treatment $\mathrm{D}\left(450 \mathrm{mg} \mathrm{kg}{ }^{-1}\right)$ on $1^{\text {st }} \mathrm{d}$ experienced many deaths, this was caused by the tolerance level of Koi fry to $A$. vera extract only until treatment $\mathrm{C}\left(300 \mathrm{mg} \mathrm{kg}^{-1}\right)$ but there were still some fish that survived because of their natural body resistance. against the attack of toxic $A$. bydrophila and saponins. On the $4^{\text {th }}$ day, the Koi fry treatment $\mathrm{D}$ that survived experienced faster healing than the other treatments marked by ulcers began to shrink and lasted on the $5^{\text {th }} \mathrm{d}$ (Figure $3 \mathrm{a}-\mathrm{b}$ ).

Koi fry at treatment $\mathrm{E}\left(600 \mathrm{mg} \mathrm{kg}{ }^{-1}\right)$ suffered total death on $1^{\text {st }} \mathrm{d}$ and $2^{\text {nd }} \mathrm{d}$ due to Koi fry which could 
not tolerate $A$. hydrophila and saponin compounds produced by $A$. vera extract at a concentration of 600 $\mathrm{mg} \mathrm{kg}{ }^{-1}$. Lukistyowati and Kurniasih (2012) stated that the occurrence of fish deaths due to the content of saponins which can cause foam in water that can be toxic to fish. Saponin is a compound that is toxic to fish especially in very dilute solutions and also has hemolysis activity which can damage red blood cells and can result in inhibited breathing processes (Podolak et al., 2010). This shows that the higher the concentration of $A$ vera extract given, the faster the Koi fry recover from MAS disease but decrease at a concentration of $450 \mathrm{mg} \mathrm{kg}{ }^{-1}$ because the saponin content is high so that it is toxic for Koi fry.
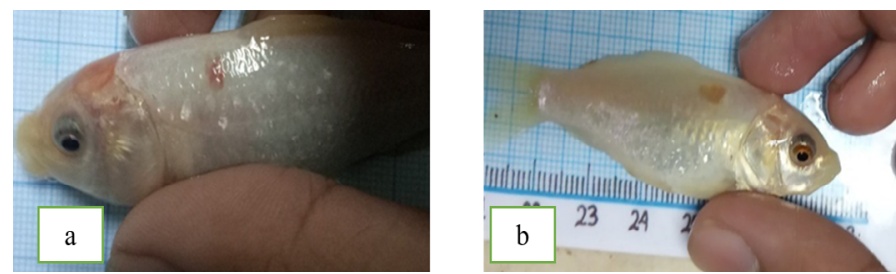

Figure 3: Healing of $A$. hydrophila clinical symptoms (a) ulcers shrink, (b) hemorraghic loss.

Compared to Tanjung (2014), the healing process of damage to carp body infected with $A$. hydrophila with the treatment of pomegranate peel extract through immersion at a concentration of $100 \mathrm{mg} \mathrm{kg}^{-1}$ tended to be longer ie reaching $11 \mathrm{~d}$ to $12 \mathrm{~d}$ to recover while the body damage to Koi fry infected with $A$. bydrophila with $A$. vera extract treatment at a concentration of $300 \mathrm{mg} \mathrm{kg}^{-1}$ recovered completely on the $7^{\text {th }} \mathrm{d}$.

The healing process of Koi fry infected with $A$. bydrophila is because $A$. vera extract contains antibacterial compounds, namely flavonoids. Flavonoid compounds are synthesized by plants as a defense system and in response to infections by microorganisms that are effective as antimicrobial compounds against a number of microorganisms (Mierziak et al., 2014). The mechanism of action of anti-inflammatory flavonoids is related to proteins through hydrogen bonds so that the structure of bacterial proteins becomes damaged, cell wall stability and plasma membranes are disrupted, then bacteria undergo lysis, so that the fish gradually heal. In addition to the flavonoids of antibacterial compounds that play an active role in healing are tannins and saponins. Ajizah (2004) explains that the mechanism of the tannin as an antibacterial can kill bacterial growth because the tannin has the power of toxicity which can result in changes in cell permeability. While saponins also help in the formation of collagen and protein structures that play a role in the process of wound healing (Suratman et al., 1996). Glucomannan also plays a role in the process of wound healing. According to (Mustaqim et al., 2017), glucomannan plays a role in restoring tissue and reducing pain due to disease and protease enzymes in collaboration with glucomannan can break down bacterial cell walls that attack wounds so that it can speed up the wound healing process.

\section{Response to feed}

In this current research, as many as 10 primers were occupied for DNA amplification at 15 genotypes of Phaseolus lunatus L. The response of eating Koi fry to all treatments after the infection has a tendency to decrease or low due to koi fry stress due to infection with $A$. bydrophila. Hamid et al. (2016) stated that the clinical symptoms that caused the change in fish behavior such as swimming on the surface of water, decreased appetite as a result of fish experiencing stress. Olga (2014) stated that the decreasing of feeding response in fish is one of the clinical symptoms of $A$. hydrophila infected the body fish.

Some of the fish in treatment $A$ on the $1^{\text {st }} \mathrm{d}$ of observation of the response to feed was low, this continued until the $12^{\text {th }} \mathrm{d}$. It was seen from the amount of leftover food deposited at the bottom of the aquarium when cleaned, then at the end of the observation, there was no response to feed because the fish experienced death (Table 3). Most of the other fish in treatment a had a normal feed response and decreased again on the $13^{\text {th }} \mathrm{d}$. It is suspected that the fish had experienced healing by its natural body resistance until the $13^{\text {th }} \mathrm{d}$, but its body resistance was no longer able to resist the attacks of $A$. bydrophila and Koi fry experiencing metabolic disorders due to the attack of $A$. bydrophila. Roy et al. (2018) stated that one of the target organs of attack of $A$.hydrophila is the kidney, where the disruption of these organs can affect the body's metabolic processes.

Treatment $B$ on the $2^{\text {nd }} \mathrm{d}$ after the treatment of Koi fry has experienced an increase in feed response until the end of maintenance. Whereas treatment $\mathrm{C}$ and $\mathrm{D}$ on $3^{\text {rd }} \mathrm{d}$ of Koi fry had an increased response to feed but had declined on the $6^{\text {th }} \mathrm{d}$ and $7^{\text {th }} \mathrm{d}$ but the following day the Koi fry had increased feed response again marked by the depletion of the feed given and the rapid reaction Koi fry for feed given. 
Table 3: The response of Koi fry feed.

\begin{tabular}{|c|c|c|c|c|c|c|c|c|c|c|c|c|c|c|c|}
\hline \multirow{4}{*}{$\begin{array}{l}\text { Days } \\
\text { to- }\end{array}$} & \multicolumn{15}{|c|}{ Response to Feed } \\
\hline & \multicolumn{3}{|c|}{ A } & \multicolumn{3}{|c|}{ B } & \multicolumn{3}{|c|}{$\mathrm{C}$} & \multicolumn{3}{|c|}{$\mathrm{D}$} & \multicolumn{3}{|c|}{$\mathrm{E}$} \\
\hline & & $\begin{array}{l}\text { epet } \\
\text { on }\end{array}$ & & & epeti & tion & $\operatorname{Re}_{1}$ & epeti & tion & & epetit & tion & & $\begin{array}{l}\text { epet } \\
\text { on }\end{array}$ & \\
\hline & 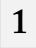 & 2 & 3 & 1 & 2 & 3 & 1 & 2 & 3 & 1 & 2 & 3 & 1 & 2 & 3 \\
\hline 1 & + & + & + & + & + & + & + & + & + & ++ & + & + & & + & - \\
\hline 2 & 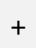 & + & + & ++ & ++ & + & + & ++ & + & + & ++ & + & & - & - \\
\hline 3 & 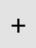 & + & + & ++ & + & + & ++ & ++ & ++ & ++ & ++ & ++ & & - & - \\
\hline 4 & 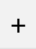 & + & + & ++ & ++ & ++ & ++ & ++ & ++ & ++ & ++ & ++ & 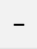 & - & - \\
\hline 5 & 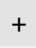 & + & + & ++ & ++ & ++ & ++ & ++ & ++ & ++ & ++ & ++ & - & - & - \\
\hline 6 & 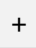 & + & + & ++ & ++ & ++ & ++ & ++ & + & ++ & + & ++ & 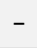 & - & - \\
\hline 7 & + & ++ & ++ & ++ & ++ & ++ & ++ & ++ & + & ++ & + & ++ & 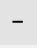 & - & - \\
\hline 8 & + & ++ & ++ & ++ & ++ & ++ & ++ & ++ & ++ & ++ & ++ & ++ & - & - & - \\
\hline 9 & + & ++ & ++ & ++ & ++ & ++ & ++ & ++ & ++ & ++ & ++ & ++ & - & - & - \\
\hline 10 & + & ++ & ++ & ++ & ++ & ++ & ++ & ++ & ++ & ++ & ++ & ++ & - & - & - \\
\hline 11 & $T$ & ++ & ++ & ++ & ++ & ++ & ++ & ++ & ++ & ++ & ++ & ++ & - & - & - \\
\hline 12 & + & ++ & ++ & ++ & ++ & ++ & ++ & ++ & ++ & ++ & ++ & ++ & - & - & - \\
\hline 13 & - & + & + & ++ & ++ & ++ & ++ & ++ & ++ & ++ & ++ & ++ & - & - & - \\
\hline+ & - & + & + & r & ++ & ++ & ++ & ++ & ++ & ++ & ++ & ++ & - & - & - \\
\hline
\end{tabular}

Compared with the Tanjung (2014) the normal feed response on carp that were attacked by $A$. bydrophila with the treatment of pomegranate peel extract through immersion took longer, namely on the $7^{\text {th }} \mathrm{d}$ while the normal feed response in the Koi fry was attacked by $A$. bydrophila using extract $A$. vera occurs on the $2^{\text {nd }} \mathrm{d}$.

Based on the results of observations, in treatment $\mathrm{E}$ on $2^{\text {nd }} \mathrm{d}$, there was no response to feed on Koi fry because the Koi fry had suffered total deaths due to the content of saponin which was toxic at a concentration of $600 \mathrm{mg} \mathrm{kg}^{-1}$.

Treatment by soaking aloe vera extract can restore the feed response of Koi fry attacked by $A$. bydrophila bacteria to normal, while treatment A (control) which was not given aloe vera extract was low until the end of the study. It is assumed that the antibacterial compounds contained in $A$. vera extracts such as flavonoids, tannins, glucomannan, and saponins have reacted and effectively inhibited and damaged $\mathrm{v}$ bacterial cells and then repaired damage to the Koi fry organ.

\section{Response to shock}

In this current research, as many as 10 primers were occupied for DNA amplification at 15 genotypes of P. lunatus. Response to shock on $1^{\text {st }} \mathrm{d}$ in all treatments showed a low response, judging from the low response of fish when tapping the aquarium wall (Table 4). It is suspected that fish experience post-infection stress and post-immersion. According to Haryani et al. (2012) that Koi fry after infection with $A$. bydropbila bacteria look stressed, swim around aeration and fish swim with sloping body position because the body balance decreases.

Table 4: Response to Shock Koi Fry.

\begin{tabular}{|c|c|c|c|c|c|c|c|c|c|c|c|c|c|c|c|c|}
\hline \multirow{4}{*}{$\begin{array}{l}\text { Days } \\
\text { to- }\end{array}$} & \multicolumn{16}{|c|}{ Response to shock } \\
\hline & \multicolumn{3}{|c|}{ A } & \multicolumn{3}{|c|}{ B } & \multicolumn{4}{|c|}{$\mathrm{C}$} & \multicolumn{3}{|c|}{$\mathrm{D}$} & \\
\hline & & pet & & $\mathrm{Re}$ & $\mathrm{p}$ & tion & & pet & $t$ & & ep & it & n & & & \\
\hline & & & & 1 & 2 & 3 & 1 & 2 & 3 & 1 & & 2 & 3 & & & 3 \\
\hline 1 & & & & + & + & + & + & + & ++ & + & & ++ & + & & & - \\
\hline 2 & & + & + & ++ & + & + & ++ & ++ & ++ & + & + & ++ & ++ & & & - \\
\hline 3 & & ++ & ++ & + & ++ & ++ & ++ & ++ & ++ & + & & ++ & ++ & . & & - \\
\hline 4 & & ++ & ++ & ++ & ++ & ++ & ++ & ++ & + & + & + & ++ & ++ & & & - \\
\hline 5 & & ++ & ++ & ++ & ++ & ++ & ++ & ++ & + & + & + & ++ & ++ & 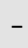 & & - \\
\hline 6 & & ++ & + & ++ & ++ & ++ & ++ & ++ & ++ & + & + & ++ & ++ & 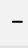 & & - \\
\hline 7 & & ++ & + & ++ & ++ & ++ & ++ & ++ & ++ & + & + & ++ & ++ & - & & - \\
\hline 0 & & ++ & & ++ & ++ & ++ & ++ & ++ & ++ & + & + & ++ & ++ & - & & - \\
\hline 9 & & ++ & + & ++ & ++ & ++ & ++ & ++ & ++ & ++ & + & ++ & ++ & - & & - \\
\hline 10 & & ++ & 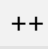 & ++ & ++ & ++ & ++ & ++ & ++ & + & + & ++ & ++ & - & & - \\
\hline 11 & & ++ & + & + & ++ & ++ & ++ & ++ & ++ & ++ & + & ++ & ++ & - & & - \\
\hline 12 & & ++ & + & ++ & ++ & ++ & ++ & ++ & ++ & ++ & + & ++ & ++ & - & - & - \\
\hline 13 & & + & + & + & ++ & ++ & + & ++ & ++ & ++ & + & ++ & ++ & - & & - \\
\hline 14 & & + & & & & ++ & & 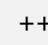 & 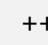 & ++ & & ++ & ++ & & - & \\
\hline
\end{tabular}

Description: -= No response or dead; += Low response shock; $++=$ Normal response shock.

The Koi fry experience changes in behavior after being infected by $A$. bydrophila bacteria, that is, the movement of slow fish and irregular swimming position of fish and always surfaces to look for oxygen. According to Haryani et al. (2012) that goldfish after being infected by $A$. bydrophila bacteria look stressful, swim around clustered around aeration and fish swim with sloping body position because the body balance decreases. Aminah et al. (2013) added that unhealthy or sick fishes look like slow movements of fish, some fish swim close to the surface or around aeration and swim with a sloping body position due to reduced body balance and damage to fish fins due to bacterial attack $A$. bydrophila

The control treatment (A) showed a stagnant or 
unchanging response, namely a low response to test 1 until the end of maintenance, but in test 2 and test 3 the shock response became normal and decreased again to a low response to surprises. Treatment B showed a normal shock response on $3^{\text {rd }} \mathrm{d}$ to the end. while the shock response of treatment $\mathrm{C}$ and $\mathrm{D}$ was normal on $6^{\text {th }}$ day, which was marked by Koi fry that had been swimming actively and was not always near aeration. E treatment had no response on $2^{\text {th }} \mathrm{d}$ because the fish had experienced total death.

Compared with the Tanjung (2014), the normal shock response in carp attacked by $A$. bydrophila with the treatment of pomegranate peel extract through immersion occurred on the $3^{\text {rd }}$ day while the shock response in the of koi fry was attacked by $A$. bydrophila with the treatment using aloe vera extract gradually normal on the $2^{\text {nd }} d$. Recovery of a shock response occurs because the antibacterial substances contained in the extract of $A$. vera have entered the body of the fish and are able to damage the bacterial cells of A. hydrophila. So that the fish attacked by the disease experience a recovery period and are able to show a normal response. Based on this research comparison of $A$. vera extract research with pomegranate extract research (Tanjung, 2014) the healing process of clinical symptoms including body damage, feed response and shock response on Koi fry attacked by $A$. bydrophila with treatment using $A$. vera extract through immersion is relatively faster compared to treatment using pomegranate peel extract through soaking. Likewise, the research results of Andriani et al. (2020) the healing process of Koi fish infected with $A$. bydrophila using telang ( $C$. ternatea) leaf extract was slower ( $9 \mathrm{~d}$ ) and lower survival (53.77 \%) than using $A$. vera extract. Because $A$. vera extract contains antibacterial compounds such as saponin, acemannan and glucomannan which is not possessed by pomegranate extract (Nozohour et al., 2018)

\section{Conclusions and Recommendations}

The results showed that the concentration of $300 \mathrm{mg}$ $\mathrm{kg}^{-1} A$. vera extracts effectively treated the of Koi fry infected with $A$. bydrophila through immersion for $48 \mathrm{~h}$. It can be seen from the healing process of body damage, response to feed and a relatively rapid shock response.

\section{Novelty Statement}

Aloe vera extract has the ability as an antibacterial 2021 | Volume 37 | Special Issue 1 | Page 71 with inhibition zone diameter reaching $20.49 \mathrm{~mm}$ at a concentration of $5000 \mathrm{mg} \mathrm{kg}^{-1}$ and LC50 test $48 \mathrm{~h}$ (in vivo test) of $1157.16 \mathrm{mg} \mathrm{kg}^{-1}$. The investigation of this research found that the concentration of 300 $\mathrm{mg} \mathrm{kg} \mathrm{kg}^{-1}$ Aloe vera extracts effectively treated the of Koi fry infected with Aeromonas bydrophila through immersion for $48 \mathrm{~h}$.

\section{Author's Contribution}

$R R$ conceptualized and designed the study, elaborated the intellectual content, performed literature search, data acquisition, data analysis, statistical analysis, manuscript preparation, and manuscript revision. $\mathrm{AN}$, $\mathrm{YA}$ and $\mathrm{KH}$ performed literature search, carried out experimental studies, data acquisition, data analysis, statistical analysis, and manuscript review. OA and AHP defined intellectual content, literature search, data analysis, manuscript review, manuscript editing, and guarantor. All authors read and approved the final manuscript

\section{Conflict of interest}

The authors have declared no conflict of interest.

\section{References}

Ajizah,A.2004. Sensitivitas Salmonella typhimurium terhadap ekstrak daun Psidium guajava L. [Sensitivity of Salmonella typhimurium to Psidium guajava L. leaf extract]. Bioscientiae, 1(1): 31-38. [in Bahasa Indonesia].

Aminah, S.B. Prayitno and Sarjito. 2014. Pengaruh perendaman ekstrak daun Ketapang (Terminalia cattapa) terhadap kelulushidupan dan histologi hati ikan mas (Cyprinus carpio) yang diinfeksi bakteri Aeromonas bydropbila [The soaking effect of Ketapang leaves (Terminalia cattapa) Extract toward survival rate and histological liver of carp infected by Aeromonas hydrophila]. J. Aquac. Manage. Technol., 3(4): 118-125. [in Bahasa Indonesia].

Andriani, Y., A.A. Handaka, Rosidah and R. Himyati. 2020. Potential of Telang plant (Clitoria ternatea) for treatment of Aeromonas bydrophila infection on Koi Fish (Cyprinus carpio). Omni-Akuatika, 16(1): 24-31. https:// doi.org/10.20884/1.oa.2020.16.1.751

Bereksi, M.S., H. Hassaïne, C. Bekhechi and D.E. Abdelouahid. 2018. Evaluation of antibacterial activity of some medicinal plants extracts 
commonly used in Algerian traditional medicine against some pathogenic bacteria. Phcog. J., 10(3): 507-512. https://doi.org/10.5530/ pj.2018.3.83

Chakraborty, S.B., P. Horn and C. Hancz. 2013. Application of phytochemicals as growthpromoters and endocrine modulators in fish culture. Rev. Aquac., 6(5): 1-19. https://doi. org/10.1111/raq.12021

Elayaraja, A., S. Muthupandi, M. Radhakrishnan and S.A. Rahaman. 2015. In vitro antioxidant and antibacterial activity of plant extracts of Pergularia extensa chiov. Int. J. Pharmacogn. Phytochem. Res., 7(3): 510-512.

Hamid, N.H., M.D. Hassan, M.Y. Sabri, A.H. Hasliza, R.H. Hamdan and M.N.F. Afifah. 2016. Studies on pathogenicity effect of Aeromonas bydrophila infection in juvenile red hybrid tilapia Oreochromis sp. Proc. Int. Semin. Livest. Prod. Vet. Technol., ICARD. https://doi.org/10.14334/Proc.Intsem.LPVT2016-p.532-539

Hamouda, T. and J.R. Baker. 2019. Antimicrobial mechanism of action of surfactant lipid preparations in enteric Gram-negative bacilli.J. Appl. Microbiol., 89(3): 397-403. https://doi. org/10.1046/j.1365-2672.2000.01127.x

Haryani, A., R. Grandiosa, I.D. Buwono and A. Santika. 2012. Uji efektivitas daun pepaya (Carica papaya) untuk pengobatan infeksi bakteri Aeromonas hydrophilapada ikan mas koki (Carassius auratus). [Test the effectiveness of Papaya leaves (Carica papaya) for the treatment of Aeromonas hydrophila bacterial infections in goldfish (Carassius auratus)]. Jurnal Perikanan dan Kelautan. 3(3): 214-220. [in Bahasa Indonesia].

Huang, Q. X. Liu, G. Zhao, T. Hu and Y. Wang. 2018. Potential and challenges of tannins as an alternative to in-feedantibiotics for farm animal production. Anim. Nutr., 4(2): 137-150. https://doi.org/10.1016/j.aninu.2017.09.004

Kar, S.K. and T.K. Bera. 2018. Phytochemical constituents of Aloe vera and their multifunctional properties: A comprehensive review. Int. J. Pharm. Sci. Res., 9(4): 1416-23.

Kartikaningsih, H., Yahya, F.Z. Rohman and A.A. Jaziri. 2020. Characteristics of Aeromonas bydrophila-infected catfish (Clarias sp.). IOP Conf. Ser Earth Environ Sci., 493(012036): 1-8. https://doi.org/10.1088/1755-

\section{5/493/1/012036}

Khan, R.U. and M. Ayub. 2020. Effect of different chemical preservatives on the quality attributes of guava Aloe vera blended pulp at ambient conditions. Sarhad J. Agric., 36 (2): 374-733. https://doi.org/10.17582/journal. sja/2020/36.2.411.418

Kozińska, A. and A. Pękala. 2012. Characteristics of disease spectrum in relation to species, serogroups, and adhesion ability of motile aeromonads in fish. Sci. World J., 2012: 1-9. https://doi.org/10.1100/2012/949358

Kraemer, S.A., A. Ramachandran and G.G.Perron. 2019. Antibiotic pollution in the environment: From microbial ecology to public policy. Microorganisms, 7(6): 180-185. https://doi. org/10.3390/microorganisms7060180

Kumar, M., G. Gupta, Vikas and S. Sharma. 2018. Feed based vaccine in aquaculture. Pro. Aqua. Farm. Marine. Biol., 1(2): 1-6.

Laith, A.R. and M. Najiah. 2013. Aeromonas bydrophila: Antimicrobial susceptibility and histopathology of isolates from diseased catfish, Clarias gariepinus (Burchell). J. Aquac. Res. Dev., 5: 1-7.

Lukistyowati, I. and Kurniasih. 2012. Pelacakan gen aerolysin dari Aeromonas hydrophila pada ikan mas yang diberi pakan ekstrak bawang putih. [Detection of aerolysin gen from Aeromonas hydrophila in common carp fed with garlic extract]. J. Vet., 13(1): 43-50. [in Bahasa Indonesia].

Mandal, S.M., R.O. Dias and O.L. Franco. 2017. Phenolic compounds in antimicrobial therapy. J. Med. Food, 20: 1031-1038. https://doi. org/10.1089/jmf.2017.0017

Mierziak, J., K. Kostyn and A. Kulma. 2014. Flavonoids as important molecules of plant interaction with the enviroment. Molecules, 19(10): 16240-16265. https://doi.org/10.3390/ molecules 191016240

Mustaqim,A.,A.Asri and Almurdi.2017.Pengaruh pemberian gel lidah buaya (Aloe vera) terhadap gambaran histopatologi gaster tikus wistar yang diinduksi indometasin. [The effect of Aloe vera gel on Wistar rat gastric histopathologic appearance]. Jurnal Kesehatan Andalas. 6(3): 641-646. [in Bahasa Indonesia]. https://doi. org/10.25077/jka.v6i3.751

Noor, E-D.A.I., S.I. Shalaby, M.S. Zaki and M.F. Abd Elzaher. 2013. Some infectious and non- 
infectious eye affection syndrome in fish. Life. Sci. J., 10(2): 1362-1368.

Nozohour, Y., R. Golmohammadi, R. Mirnejad and M. Fartashvand. 2018. Antibacterial activity of pomegranate (Punica granatum L.) seed and peel alcoholic extracts on Staphylococcus aureus and Pseudomonas aeruginosa isolated from health centers. J. Appl. Biotechnol., 5(1):32-36. https://doi.org/10.29252/JABR.01.01.06

Olga, O., 2014. Patogenisitas bakteri Aeromonas bydrophila ASB01 pada ikan Gabus (Ophicephalus striatus). [Pathogenicity of Aeoromonas bydrophila ASB01 bacteria in Cork fish (Opbicephalus striatus)]. Sains Akuatik, 14(1): 33-39. [in Bahasa Indonesia].

Panche A.N., A.D. Diwan, and S.R. Chandra. 2017. Flavonoids: An overview. J. Nutr. Sci., 5: 1-15. https://doi.org/10.1017/jns.2016.41

Pandey, A., M. Naik and S.K. Dubey. 2010. Hemolysin, protease, and EPS producing pathogenic Aeromonas hydrophila strain An4 shows antibacterial activity against marine bacterial fish pathogens. J. Mar. Res., 2010: 1-9. https://doi.org/10.1155/2010/563205

Peatman, E., H. Mohammed, A. Kirby, C.A. Shoemaker, M.A. Yildirim and B.H. Beck. 2018. Mechanisms of pathogen virulence and host susceptibility in virulent Aeromonas bydrophila infections of channel catfish (Ictalurus punctatus). Aquaculture, 482: 1-8. https://doi. org/10.1016/j.aquaculture.2017.09.019

Podolak, I., A. Galanty and D. Sobolewska. 2010. Saponins as cytotoxic agents: A review. Phytochem. Rev. 9(3): 425-474. https://doi. org/10.1007/s11101-010-9183-z

Quezada, M.P., C. Salinas, M. Gotteland and L. Cardemil. 2017. Acemannan and fructans from Aloe vera (Aloe barbadensis Miller) plants as novel prebiotics. J. Agric. Food. Chem., 65: 10029-10039. https://doi.org/10.1021/acs. jafc. $7 \mathrm{~b} 04100$

Roy, A., J. Singha and T.J. Abraham. 2018. Histopathology of Aeromonas caviae infection in challenged Nile tilapia Oreochromis niloticus (Linnaeus, 1758).Int.J.Fish.Aquac., 8(20):151155. https://doi.org/10.5376/ija.2018.08.0020

Safaria, M. and A.S. Asbchinb. 2019. Evaluation of antioxidant and antibacterial activities of methanolic extract of medlar (Mespilus germanica L.) leaves. Biotechnol. Biotechnol. Equip., 33(1): 372-378. https://doi.org/10.108
0/13102818.2019.1577701

Sahu, P.K., D.D. Giri, R. Singh, P. Pandey, S. Gupta, A.K. Shrivastava, A. Kumar and D.K. Pandey. 2013. Therapeutic and medicinal uses of Aloe vera: A review. Pharm. Pharmacol., 4(8): 1-13.

Samsudin, N.I.P., H.Y. Lee, P.E. Chern, C.T. Ng, L. Panneerselvam, S.Y. Phang, W.T. Tan and N.A. Mahyudin. 2018. In vitro antibacterial activity of crude medicinal plant extracts against ampicillin+ penicillin-resistant Staphylococcus aureu. Int. Food Res. J., 25(2): 573-579.

Sengul, M., H. Yildiz, N. Gungor, B. Cetin, Z. Eser and S. Ercisli. 2009. Total phenolic content, antioxidant and antimicrobial activities of some medicinal plants. Pak. J. Pharm. Sci., 22: 102106.

Septriarusli, I.E., H. Kiki, M. Yenny and M. Danar. 2012. Potential secondary metabolite compounds from seed extract of Keben fruit Barringtonia asiatica in anesthesia process of tiger grouper Ephinephelus fuscoguttatus. J. Fish. Mar., 3: 295-299.

Sopiah, S., R. Rosidah, W. Lili, I. Iskandar and I.B. Suryadi. 2018. The effectivity of pandanus leaf extract for the treatment of Sangkuriang catfish juvenile Clarias gariepinus infected by Aeromonas hydrophila. J. Akuakultur Indonesia, 17(2): 120-129.

Suratman, S.A. Sumiwi and D. Gozali. 1996. Pengaruh ekstrak antanan dalam bentuk salep, krim dan jelly terhadap penyembuhan luka bakar. [Effects of Antananas extract in the form of ointments, creams and jelly on healing burns]. Cermin Dunia Kedokteran, 108: 31-36. [in Bahasa Indonesia].

Tanjung, A.F., 2014. Efektivitas ekstrak kulit buah delima dalam pengobatan benih ikan mas (Cyprinus carpio) yang terinfeksi bakteri Aeromonas bydrophila. [Effectiveness of pomegranate skin extract in the treatment of carp (Cyprinus carpio) seeds infected by Aeromonas hydrophila bacteria]. [Undergraduate Thesis]. Faculty of Fisheries and Marine Science, Padjadjaran University, Bandung. [in Bahasa Indonesia].

Triyanti, R. and M. Yulisti. 2012. Rantai pemasaran ikan koi (Cyprinus carpio) di Kabupaten Blitar, Jawa Timur. [Marketing chain of koi fish (Cyprinus carpio) in Blitar Regency, East Java]. Buletin Riset Sosek Kelautan dan Perikanan, 7(1): 14-20. [in Bahasa Indonesia]. https://doi. 
org/10.15578/marina.v7i1.4593

United State Environmental Protection Agency (USEPA). 2002. Methods for measuring the acute toxicity of effluents and receiving waters to freshwater and marine organisms. Office of Water (4303T) 1200 Pennsylvania Avenue, NW Washington, DC 20460.

Wassif, I.M., 2018. Biochemical and molecular characterization of Aeromonas species isolated from fish. Alex. J. Vet. Sci., 57 (1): 38-45. https://doi.org/10.5455/ajvs.293293 